\title{
CLASSIFICATION AND BIOLOGICAL ACTIVITY OF PHYTOESTROGENS: A REVIEW
}

Ivana Lj. Nikolić”, Ivana M. Savić-Gajić, Ana D. Tačić, Ivan M. Savić

Faculty of Technology, University of Niš, Leskovac, Serbia

Phytoestrogens represent polyphenolic and non-steroid compounds that have a similar structure and biological activity as human estrogens. They are the plant secondary metabolites and widespread in over 300 various plant species. The phytoestrogens are divided into two main subgroups, isoflavonoids and lignans. The isoflavonoids are divided into isoflavones and coumestans. Isoflavones are most present in soybean and red clover. A great number of isoflavones has been identified in the plants in the form of non-active glycosides (daidzein and genistein) and in the form of 4'-methylated derivatives (formononetin and biochanin A). Coumestans can also be found in red clover and legumes, while lignans are most present in the flax seed. Coumestans have the most pronounced estrogenic effect of all phytoestrogens. The most famous representative of this subgroup of compounds is coumestrol. Lignans include matairesinol, secoisolariciresinol, lariciresinol, pinoresinol and their metabolites, enterodiol, enterolactone and equol. Numerous studies in animals and humans have shown that phytoestrogens can have protective effects in the estrogen-dependent conditions and estrogen-dependent diseases. It was also shown that the use of phytoestrogens can have a positive effect on insomnia and cognitive functions, i.e. neural disorders, such as Alzheimer's disease. They can express the antioxidant activity in two ways, as the scavengers of free radicals or by the formation of chelating complexes with metal ions. Free metal ions increase the amount of reactive oxygen species by reduction of hydrogen peroxide resulting in a very reactive hydroxyl radical.
(REVIEW PAPER)

UDC 577.175.6:615.322.07

Keywords: phytoestrogens, classification, pharmacological activity

\section{Introduction}

Plants synthesize a large number of compounds that can be divided into primary and secondary metabolites. Primary metabolites play an essential role in photosynthesis, respiration, the growth and development of the plants. Phytosterols, acyl lipids, nucleotides, amino acids and organic acids are included in this group. Secondary metabolites have no nutritional value, but exhibit various biological activities. They are present in a limited number of plant species and very different in structure. These compounds are involved in the protection of plants from infections and UV irradiation. They play an important role in the pollination and fixation of nitrogen in the root nodules of legumes. They are a potential source of new and natural drugs, antibiotics, insecticides and herbicides $[1,2]$.

Secondary metabolites are divided into three main groups [1]:

- flavonoids, related phenolic and polyphenolic compounds

- terpenoids and

- nitrogen-containing alkaloids and the compounds of sulfur.

Due to the important biological activity, secondary metabolites are the subject of many studies. The insufficient intake of secondary metabolites during a long period of time increases the incidence of cancer and other chronic, non-infectious diseases including a cardiovascular disease and diabetes mellitus type II. Phytoestrogens represent the group of natural products that, due to the structural similarity with the female sex hormones, have the biological activity as estrogens $[1,2]$. Experimental investigations indicate that the consummation of foods rich in phytoestrogens can have a protective effect on the estrogen-dependent conditions (menopausal symptoms) and estrogen-dependent diseases (prostate cancer and breast cancer, osteoporosis and cardiovascular disease) [3]. This review will attempt to briefly illustrate the classification and significance of the phytoestrogens application in the treatment of various human diseases or, in other words, to describe pharmacological activities of phytoestrogens.

\section{Phytoestrogens}

Phytoestrogens were developed in 1926. The name comes from the Greek word phyto (,plant") and estrogen which means a sex hormone [2]. The compounds with es-

\footnotetext{
* Author address: Ivana Lj. Nikolić, Faculty of Technology, University of Niš, Bulevar oslobodjenja 124, 16000 Leskovac, Serbia

E-mail: ivananikolic1991@yahoo.com

The manuscript received: April,28, 2017.

Paper accepted: August,16, 2017.
} 
trogenic effects are present in more than 300 various species, but most of them are contained in leguminous [4,5]. Phytoestrogens are diphenolic, non-steroidal substances of vegetable origin, belonging to the first group of secondary plant metabolites or a group of flavonoids and related phenolic and polyphenolic compounds [6,7]. This class of compounds represent a diverse group of plant substances, where they or their active metabolites have a biological activity similar to human estrogens. The division of phytoes- trogens is based on their chemical structure. The important class of phytoestrogens are flavanones, flavonoids, isoflavonoids, coumestans, chalcones, stilbenes and lignans. The most significant group of phytoestrogens are isoflavonoids $[8,9]$. These compounds have a steroidal structure that is similar to the structure of steroidal estrogens, which allows them to exhibit estrogenic and anti-estrogenic effects [10]. In Figure 1, the classification of phytoestrogens is depicted [1-4].

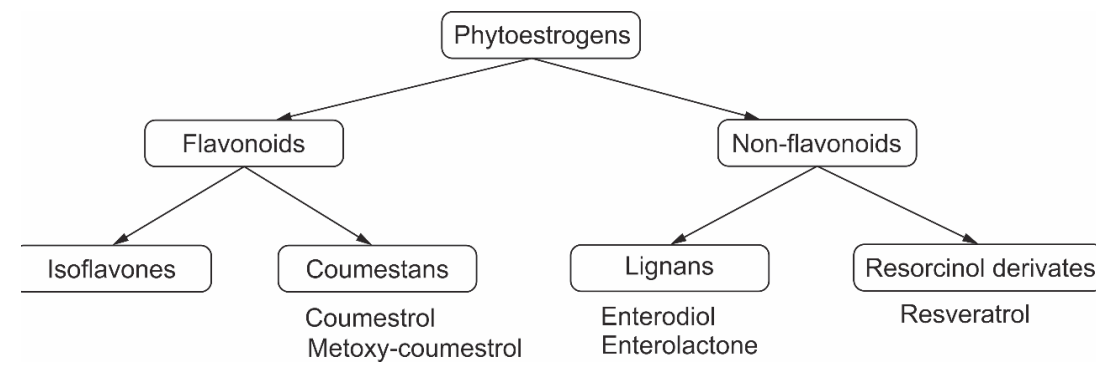

Figure 1. Classification of phytoestrogens.

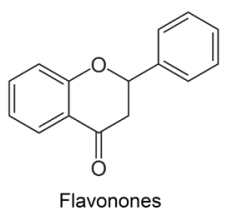<smiles></smiles><smiles>CCCCCOC(C)(C)C</smiles><smiles>CC(C)OC(=O)/C=C/c1ccccc1</smiles><smiles>O=c1oc2ccccc2c2oc3ccccc3c12</smiles>

Coumestans<smiles>C(=C/c1ccccc1)\c1ccccc1</smiles><smiles>c1ccc(CC2COCC2Cc2ccccc2)cc1</smiles>

Lignans

Figure 2. General structures of a certain class of phytoestrogens.

General structures of a certain class of phytoestrogens are presented in Figure 2.

\section{Flavonoids}

Flavonoids are widely distributed in nature, especially in higher plants belonging to Leguminoseae, Rutaceae, Primulaceae, Polygonaceae, Salicaceae, Pinaceae, Rosaceae families etc. [11]. Flavonoids are polyphenols represented in fruits, vegetables and some plants such as tea [12,13], ginger root [14] etc. Flavonoids are substances that are synthesized only in plants. Isoflavones and coumestans belong to the group of flavonoid phytoestrogens. They are a very specific group of flavonoids where $\mathrm{B}$ ring is bonded in the position 3 of $\mathrm{C}$ ring. Isoflavones in the aglycone form are different from each other according to the arrangement of substituents. Bonding of one molecule of glucose for the hydroxyl group in position 7 results in the formation of 7-O-glycoside of isoflavones. In plants, this is the most common group of isoflavon glycosides. They can exist in the form of acetylglycosides and malonyl-glycoside $[2,15]$.
A large number of isoflavones have been identified in plants in the form of non-active glycosides (daidzin and genistin) and in the form of 4'-methylated derivative (formononetin and biochanin A). Hydroxyl groups and sugars increase the solubility of isoflavones in water, while methyl groups, isopentyl units, and other similar substituents cause that the molecules of isoflavone are lipophilic [1]. General structures of aglycones and glycosides of isoflavones in plants are presented in Figure 3 and Table 1 [2,3,15].

Table 1. The most common isoflavones (aglycones and glycosides) in nature

\begin{tabular}{lllll}
\hline \multicolumn{1}{c}{ Aglycon } & \multicolumn{1}{c}{ Glicoside } & $\mathbf{R}_{\mathbf{1}}$ & $\mathbf{R}_{\mathbf{2}}$ & $\mathbf{R}_{\mathbf{3}}$ \\
\hline daidzein & daidzin (daidzein-7-glucoside) & $\mathrm{H}$ & $\mathrm{H}$ & $\mathrm{OH}$ \\
genistein & genistin (genistein-7-O-glucoside) & $\mathrm{OH}$ & $\mathrm{H}$ & $\mathrm{OH}$ \\
glycitein & glycitin (glycitein-7-O-glucoside) & $\mathrm{H}$ & $\mathrm{OCH}_{3}$ & $\mathrm{OH}$ \\
formononetin & ononin (formononetin-7-O-glucoside) & $\mathrm{H}$ & $\mathrm{H}$ & $\mathrm{OCH}_{3}$ \\
biochanin A & sissotrin (biochanin A-7-O-glucoside) & $\mathrm{OH}$ & $\mathrm{H}$ & $\mathrm{OCH}_{3}$ \\
\hline
\end{tabular}


<smiles>[R9]c1ccc(-c2coc3cc(O)c([R3])c([R])c3c2=O)cc1</smiles>

a)

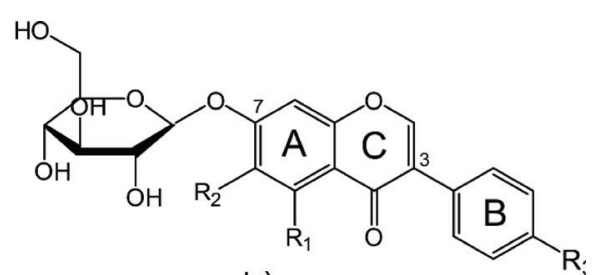

b)

Figure 3. General structure of isoflavones: a) aglycones, b) glycosides.

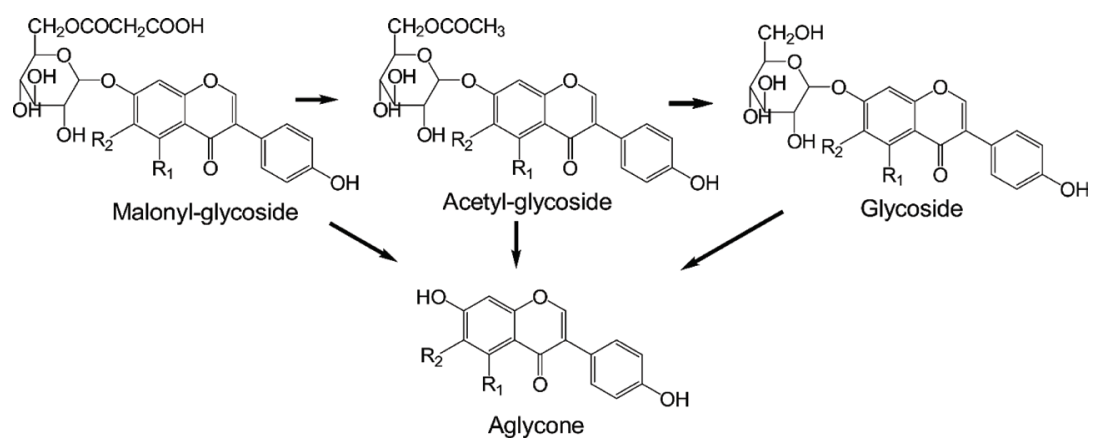

Figure 4. The most common possible ways of isoflavones decomposition.

Isoflavone phytoestrogens are present in only a few plants. They are found only in the plants of the Fabaceae family. Only a few species have been proven to be rich in isoflavones (Table 2). The composition and content of isoflavones varies widely (Table 3 ) $[2,5,15]$.

The acetyl- and malonyl-forms of isoflavones, as well as their glycosides are the subject to degradation in acidic and alkaline medium, resulting in the formation of corresponding aglycones. Most common chemical transformations are decarboxylation of malonyl-glycosides and hydrolysis of malonyl- and acetyl-esters to the glycosides. The aglycones of isoflavones are formed by degradation of glycosidic bonds. Possible ways of isofla- vones degradation are depicted in Figure 4 [15].

The procedure of glycoside hydrolysis can be carried out before, during and after the extraction of isoflavones. There are two basic ways to carry out the hydrolysis of isoflavones: alkaline and acidic hydrolisis [16]. For instance, hydrochloric acid (the concentration of $0.13 \mathrm{~mol} \mathrm{dm}^{-3}$ ) provides the complete hydrolysis at the temperature over $80{ }^{\circ} \mathrm{C}$ [17]. In recent years, the enzymatic hydrolysis using $\beta$-glucosidase has been applied to hydrolyze glycosides of isoflavones to the appropriate aglycones $[16,18]$. The acidic hydrolysis of genistin to genistein is presented in Figure 5.

Table 2. The isoflavone content in certain plant species

\begin{tabular}{ll}
\hline \multicolumn{1}{c}{ Plant species } & \multicolumn{1}{c}{ The isoflavone content } \\
\hline alfalfa (Medicago sativa) & $0.5-3.5 \%$ \\
mung bean (Vigna radiata) & $3.51 \mathrm{mg} / \mathrm{kg}$ crude sample \\
kudzu root (Pueraria lobata) & $0.95 \mathrm{~g} / \mathrm{kg}$ daidzein \\
psoralea (Psoralea corylifolia) & $2 \mathrm{~g} / \mathrm{kg}$ dried sample \\
red clover (Trifolium pratense) & $1.5-2.5 \%$ \\
soybean (Glycine max) & $0.1-0.5 \%$ \\
\hline
\end{tabular}

Table 3. The composition of isoflavones in certain plant species

\begin{tabular}{ll}
\hline \multicolumn{1}{c}{ Plant species } & \multicolumn{1}{c}{ The main isoflavones } \\
\hline soybean (Glycine max) & daidzein, genistein, glycitein \\
red clover (Trifolium pratense) & daidzein, genistein, formononetin, biochanin A \\
kudzu root (Pueraria lobata) & puerarin, daidzein, genistein \\
chickpea (Cicer arietinum) & biochanin A, genistein \\
alfalfa (Medicago sativa) & formononetin, coumestrol \\
\hline
\end{tabular}




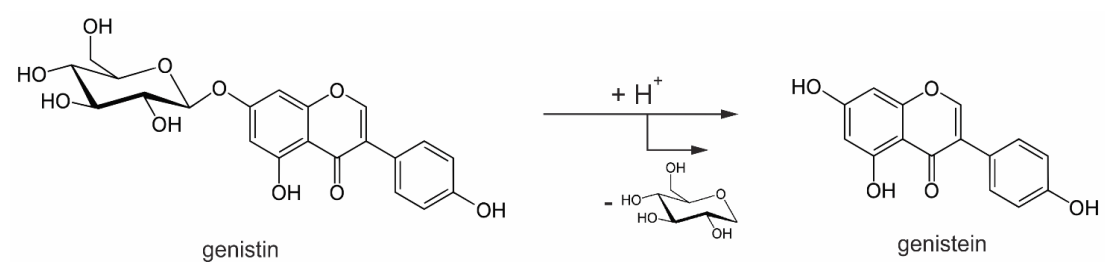

Figure 5. The removal of glucose from genistinin position 7 and the genistein formation by hydrolysis.

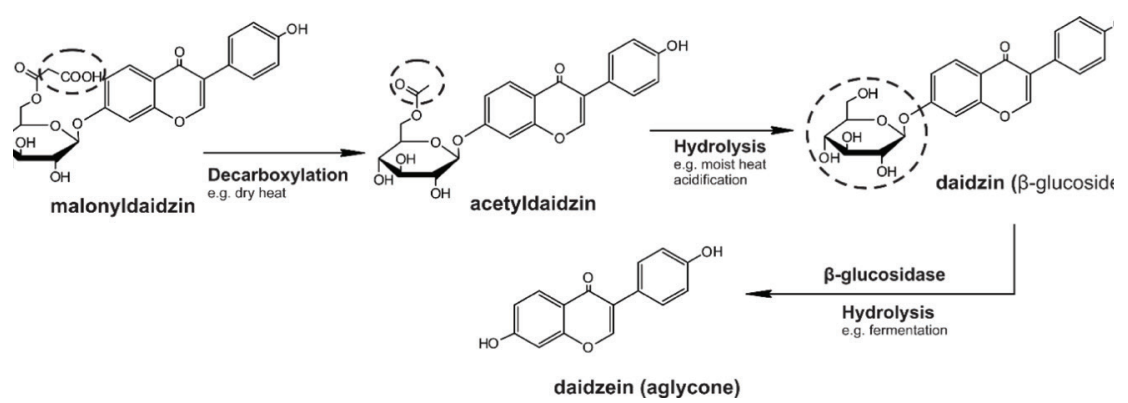

Figure 6. Transformation of daidzin conjugates to daidzein aglycone.

Isoflavones from foods can be degraded in the human organism by the action of enzymes of the digestive tract and by the processes of fermentation, resulting in the formation of bioactive aglycones. The transformation of the daidzin conjugate to aglycone (daidzein) is given in Figure 6 [17].

Aglycones of isoflavones are relatively resistant to degradation in the gastrointestinal tract, and mainly absorbed from the colon. Some of aglycones such as daidzein and genistein are converted into metabolites in the digestive tract. Equol is a relatively stable active metabo- lite of daidzein and possesses a more estrogenic activity than its precursor daidzein [15]. It binds to both forms of estrogen receptors and has a high antioxidant activity. The investigations have shown that people do not have an equal ability to produce equol [5]. In addition to equol, daidzein gives other metabolites such as 7-glucuronide (54\%), 4'-glucuronide (25\%), monosulfate $(13 \%)$, free aglycone $(7 \%)$, sulfoglucuronide $(0.9 \%)$, diglucuronide $(0.4 \%)$, disulfate $(0.1 \%)$, dihydrodaidzein and O-desmetylangolensin under the action of bacteria of the intestinal flora. Their structures are presented in Figure 7.

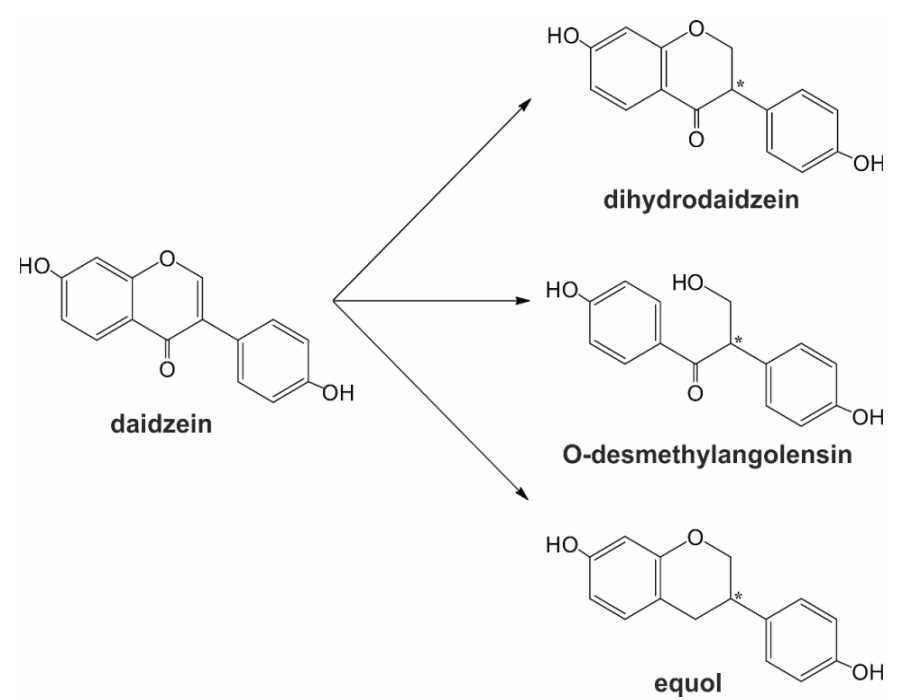

Figure 7. The structure of specific metabolites of daidzein.<smiles>O=c1oc2cc(O)ccc2c2oc3cc(O)ccc3c12</smiles><smiles>CC12CCC3c4ccc(O)cc4CCC3C1CCC2O</smiles>

Figure 8. Chemical structures of: a) coumestrol, b) $17 \beta$-estradiol. 
Glucuronides have a weak estrogenic activity and may be able to activate natural killer cells that help in the fight against cancer. Genistein and daidzein give metabolites in the digestive tract such as genistein glucuronide, dihydrogenistein-glucuronide, genistein sulfate, dihydrogenistein and 6'-hydroxy-O-desmetylangolesin [5].

In addition to isoflavones, flavonoids also include coumestans. In the literature, it has been reported that coumestans have the most pronounced estrogenic effect of all phytoestrogens. The best known representative of this subgroup of compounds is coumestrol [5,9]. It was first identified in 1957 as a clover compound, which has 30 to 100 times higher estrogenic activity than isoflavones [19]. Also, it can be found in spinach, brussels sprout and legumes such as soybeans [20]. In its structure, coumestrol has two hydroxyl groups in the same position as $17 \beta$-estradiol, which enables to inhibit the activity of aromatase and $3 \beta$-hydroxysteroid dehydrogenase [21]. These enzymes are included in the biosynthesis of steroid hormones, and their inhibition interferes with the metabolism of hormones [22]. Chemical structures of coumestrol and 17ß-estradiol are shown in Figure 8.

\section{Lignans}

Lignans are biologically active phenolic compounds of the plant origin with a weak estrogenic activity. Lignans were first detected in the plants in which they help in the formation of lignin used to construct the plant cell wall [23]. They are widespread and their content is highest in flax seed, sesame seed, wheat germ and rye.
The content and composition of lignans in certain plant species are given in Table 4 and Table 5, respectively.

Table 4. The lignan content in certain plant species

\begin{tabular}{ll}
\hline \multicolumn{1}{c}{ Plant species } & \multicolumn{1}{c}{$\begin{array}{c}\text { The lignan } \\
\text { content per } 100 \mathrm{~g}\end{array}$} \\
\hline flax seed (Linum usitatissimum L.) & $0.3 \mathrm{~g}$ \\
sesame seed (Sesamum indicum L.) & $29 \mathrm{mg}$ \\
cabbages & $185-2321 \mu \mathrm{g}$ \\
cereals & $7-764 \mu \mathrm{g}$ \\
\hline
\end{tabular}

Table 5. The composition of lignans in certain plant species

\begin{tabular}{ll}
\hline \multicolumn{1}{c}{ Plant species } & \multicolumn{1}{c}{ The main lignans } \\
\hline flax seed (Linum usitatissimum L.) & $\begin{array}{l}\text { secoisolariciresinol, } \\
\text { matairesinol }\end{array}$ \\
sesame seed (Sesamum indicum L.) & sesamolin \\
cereals grain (rye, barley, wheat) & syringaresinol \\
fruits (berries and nuts) & medioresinol \\
\hline
\end{tabular}

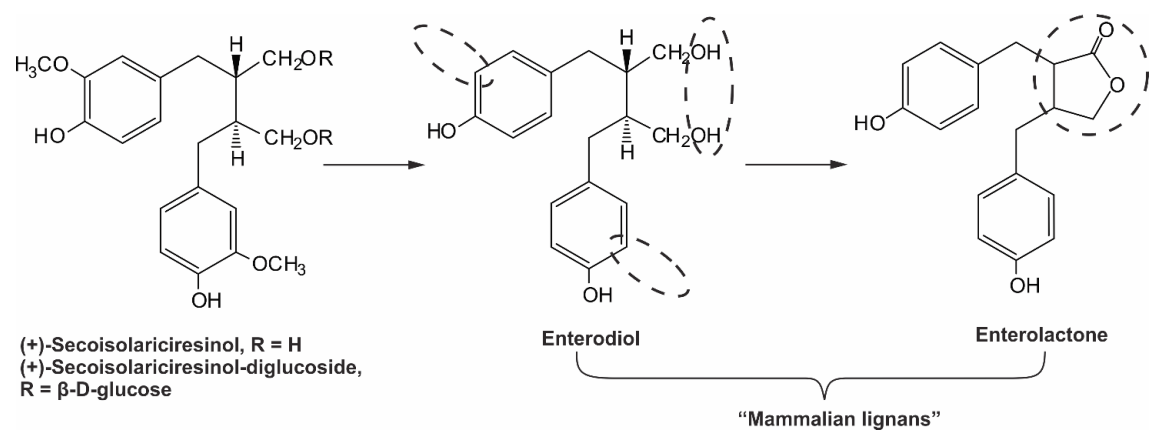

Figure 9. Degradation of secoisolariciresinol and its diglucoside in the human intestine to "mammalian lignans" (enterodiol and enterolactone).

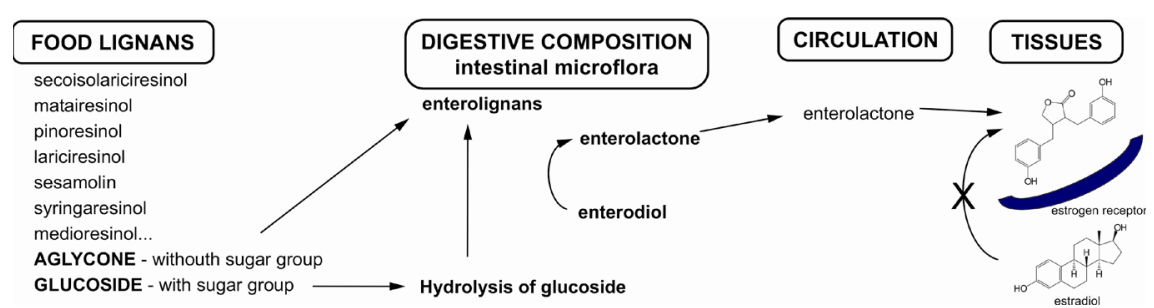

Figure 10. Metabolism of lignans and action in a mammalian organism.

Lignans is a group of natural non-flavonoid phytoestrogens. They have two phenylpropane units (C6-C3) connected via two specific carbons (C-2-C-2') in their structure. The plant lignans may occur in the form of aglycones and glycosides. After consummation, lignans are transformed into enterolignane metabolites by the effect of enzymes of the digestive tract. They exhibit the estrogenic activity and other biological activities impor- 
tant for the preservation of human health [24]. In flax seed, there are two main lignans and these are secoisolariciresinol and matairesinol glycosides. They exert the estrogenic activity via their metabolites enterodiol and enterolactone, also known as "mammalian lignans“ $[5,25]$. The transformation of secoisolariciresinol and its glycosides to active metabolites under the enzyme action of the digestive tract are presented in Figure 9.

The formed enterolignans (enterodiol and enterolactone) are absorbed from the gastrointestinal tract and excreted in urine [26]. The enterolignans achieve the estrogenic activity by binding to the estrogen receptor, wherein the estrogen-receptor complex is formed. This complex has a weaker estrogenic activity from the endogenous estrogen-receptor complex. It is important for women who naturally have a high content of endogenous estrogens because enterolignans bind to the estrogen receptors. In other words, they compete with endogenous estrogens thereby decreasing the total estrogenic activity [27]. Lignans from flax seed and sesame seed also have the antiestrogenic activity by blocking the estrogenic effect in some tissues. In this way, they reduce the risk of hormone dependent cancers such as the breast cancer, ovarian, uterine and prostate cancers [28]. In Figure 10, the metabolism of lignans and their effect in the mammalian organism are presented.

\section{Resorcinol derivatives}

The main representative of this group of non-flavonoid phytoestrogens is resveratrol. It belongs to stilbenes, plant phenolics with a diaryl-1,2-ethene structure. The chemical structure of trans-resveratrol is given in Figure 11.

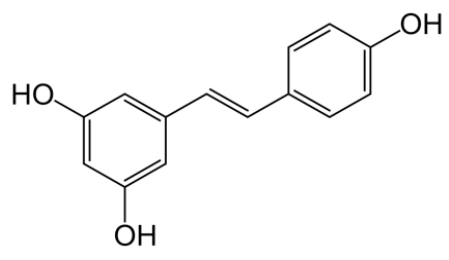

Figure 11. The chemical structure of trans-resveratrol.

Stilbene monomers, dimers and polymers occur widely among liverworts and higher plants [29]. trans-Resveratrol and related compounds are well known as phytoalexins ingrapes (Vitis vinifera L., Vitaceae). Significant amounts are also found in peanuts (Arachis hypogaea L., Leguminosae), as well as in rhizomes and roots of various species of Polygonaceae. In nutraceuticals, the extracts of Fallopia japonica are used as a source of resveratrol. It has been shown that resveratrol exhibits the estrogenic [30], antioxidant [31], antiviral [32], antiplatelet [33], anti-thyroid [34] and cancer chemopreventive activity [35]. Furthermore, resveratrol enhances the expression and activity of endothelial nitric oxide synthase [36] and induces vasorelaxation [37]. Resveratrol has the inhibitory effect on enzyme $\alpha$-glucosidase which can be a potential mechanism of its antidiabetic activity [38].
Cvetkovic et al. [39] confirmed that trans-resveratrol is a photosensitive substance which transforms from trans to cis form after the effect of UV irradiation.

\section{Biological activity of phytoestrognes}

Due to their structural similarity with human estrogens phytoestrogens achieve most of their biological effects by binding to estrogen receptors (ER). However, isoflavones may exhibit effects on the human organism in other ways such as:

- Inhibition of the synthesis and activity of certain enzymes involved in estrogen metabolism, thus altering biological effects of endogenous estrogen and testosterone;

- Inhibition of the tyrosine kinase enzyme which plays an important role in signaling pathways, thereby affecting the cell proliferation;

- The isoflavone antioxidant activity protects the human organism from the oxidative stress [40].

Phytoestrogens as a selective modulator of the estrogen receptor

Two subtypes of the human estrogen receptor exist - ER $\alpha$ and ER $\beta$ which differ in the structure and tissue distribution. ERa exhibit a high expression in the uterus, testicles, ovaries and kidneys, whereas ER $\beta$ are mainly expressed in the prostate, uterus, ovaries, testicles, bones, lungs and brain. ERa play a role in the cell proliferation while ER $\beta$ are involved in the cell differentiation and apoptosis $[3,41]$.

Isoflavones can bind to both subtypes of ER, although they have a higher binding affinity to the subtype ERB. Such a specific affinity for ER allows the isoflavones to express estrogenic and antiestrogenic effects, depending on the tissue type and the endogenous estrogen content. For example, genistein has an antiestrogenic effect in various cell lines in the presence of the adequate concentration of endogenous estradiol $\left(1 \mathrm{nmol} / \mathrm{dm}^{3}\right)$. Also, genistein has an additional estrogenic effect at lower concentrations of estradiol $\left(0.01 \mathrm{nmol} / \mathrm{dm}^{3}\right)$, which is typical in postmenopausal women [40]. The relative isoflavone affinity for binding to ER decreases in the following order: $17 \beta$-estradiol>coumestrol>genistein>equol>daidzein> $>$ biochanin A. Coumestrol is the most active isoflavonoid which has the same binding affinity for ER $\alpha$ and ER $\beta$ as $17 \beta$-estradiol and the same inducing effect on transcription as genistein. Genistein, daidzein and equol have a greater binding affinity to ER $\beta$ than to ERa. However, the isoflavone concentration required for induction is almost the same for both ER subtypes and is much higher than expected based on the binding affinity. Isoflavone glycosides (daidzin, genistin and glycitin) bind weakly to ERs and have a poor effect on the ER-dependent transcriptional expression. Genistin stimulates the growth of MCF-7 cells more strongly than genistein. Formononetin and biochanin A exhibit a significantly lower binding affinity and transcription induction than non-methylated forms (daidzein and genistein). Therefore, the metabolic 
transformation of formononetin and biochanin A by intestinal microflora is necessary for the estrogenic activity [3].

In comparison with endogenous estrogen, isoflavones are weaker estrogens. The estrogen activity of various phytoestrogens compared to $17 \beta$-estradiol is given in Table 6 [40,42].

Table 6. Relative estrogen activity in comparison with $17 \beta$-estradiol

\begin{tabular}{lc}
\hline Compound & Relative activity of estrogen \\
\hline 17ß-estradiol & 100 \\
coumestrol & 0.202 \\
genistein & 0.084 \\
equol & 0.061 \\
daidzein & 0.013 \\
formononetin & 0.0006 \\
\hline
\end{tabular}

However, regardless the low isoflavone potency in comparison with endogenous estrogen, phytoestrogens can exhibit various biological effects in the human organism. Numerous epidemiological and experimental studies in animals and humans have shown that the consumption of food rich in phytoestrogens has protective effects in the estrogen-dependent conditions, such as menopausal symptoms and estrogen-dependent diseases, such as prostate and breast cancer, osteoporosis and cardiovascular diseases [41].

The effects on the malignant diseases

Epidemiological studies have shown that breast cancer incidence and mortality in the Western world are much higher than in Asian countries, which is associated with the low phytoestrogens intake through food. The average daily intake of soybean and isoflavones in the Asian population has been estimated at $50 \mathrm{~g} /$ day and $30 \mathrm{mg} /$ day, respectively, while in the Western population the intake is limited to $1 \mathrm{~g} /$ day and $1 \mathrm{mg} /$ day [3]. The studies on animals have shown that a higher content of phytoestrogens in the diet leads to a healthier reproductive status. In addition, the experimental animals with the low phytoestrogens content in the diet show a tendency towards obesity and altered glucose regulation later in life. Also, these effects become more pronounced with each successive generation [41]. Numerous studies of phytoestrogens demonstrate their ability to inhibit the formation and development of hormonal cancers. The high isoflavones intake through diet has been linked to the decreased risk of the breast cancer development.

Antitumor isoflavone effects involve different mechanisms. Namely, isoflavones act as selective estrogen receptor modulators (SERM), but they also induce apoptosis, affect the gene expression and different enzyme systems reducing the increased estrogen activity in hormone-dependent tissues. Phytoestrogens affect the activity of various enzymes such as aromatase, dehydrogenase, sulfotransferase and reductase. Genistein can inhibit tyrosine kinase, topoisomerase, aromatase, dehydrogenase and other enzymes involved in signal transduction, DNA replication, transcription and DNA reparation. Genistein and daidzein also induce apoptosis in the breast and ovarian cancer cell lines [41].

Biochanin $A$ has a multiphasic activity on human breast carcinoma cells. Namely, it stimulates the cell growth at very low concentrations $\left(10 \mu \mathrm{g} / \mathrm{cm}^{3}\right)$, and shows cytostatic and cytotoxic effects at higher concentrations. Genistein is unique among numerous flavonoid and isoflavonoid compounds in having both strong estrogenic activity and a strong inhibitory effect on the breast cancer cells growth. In contrast, equol has a strong estrogenic activity but a poor growth inhibitory effect. Genistein is more effective in the growth inhibition of non-neoplastic breast cancer cell lines than in the growth inhibition of cancer cells. This fact supports the conclusion that early exposure to genistein may have an important effect on the breast cancer prevention [5].

It has been shown that phytoestrogens consumption is associated with a decreased risk of prostate cancer. Genistein performs down-regulation of androgenic receptors and limits androgen-stimulated prostate proliferation. Daidzein also has the ability to block the proliferative effects of testosterone on the prostate in animal models. Isoflavones can slow the growth and induce the apoptosis of prostate cancer cells in vitro and in vivo. The mechanism of the phytoestrogens action includes the inhibition of dehydrogenase, aromatase and $5 \alpha$-reductase enzymes. Another possible mechanism of action is phytoestrogens binding to $E R \beta$, which are predominantly present in the prostate $[3,41]$.

Unlike breast and prostate cancer, colon cancer is not significantly associated with the hormone status. Soybean and isoflavones have no protective effect on colon cancer. However, foods rich in lignans and lignans can inhibit the colon cancer development in animal models. Therefore, a linkage between lignans intake and the risk of colon cancer requires further investigation [3].

Estrogen replacement therapy (ERT)

The estrogen replacement therapy is recommended for women in menopause in order to prevent the menopausal symptoms, osteoporosis and cardiovascular diseases. However, despite beneficial effects, $80 \%$ of women cannot be subjected to the hormonal therapy for medical or personal reasons, including the increased risk of thrombosis, liver disorders or cancers. Concern over the ERT application in menopausal women has led to the increasing use of non-steroidal, estrogen-like substances such as phytoestrogens [42].

Isoflavone phytoestrogens stimulate the osteoblastic bone formation, inhibit the osteoclastic bone resorption and prevent the excessive bone mass loss in mice and rats with removed ovaries. The proposed mechanism of action involves the stimulation of the osteoblasts proliferation and their protection from oxidative stress, as 
well as apoptosis of osteoclast progenitors. Despite the beneficial estrogen effects, concern over the possibility of causing breast cancer still exists. Therefore, there is a growing interest in the substitution of ERT by phytoestrogens $[3,5]$.

The best results in the osteoporosis prevention have been obtained for ipriflavone (7-isopropoxyisoflavone) showing that it represents a useful and safe alternative to ERT. Ipriflavone is a synthetic isoflavone which represents a daidzein derivative. It is observed that ipriflavone does not bind to ER and therefore it is not strictly a phytoestrogen. However, about $10 \%$ of the ipriflavone applied dose can be converted to daidzein in the human organism. Clinical studies of the effects of phytoestrogens and food containing phytoestrogens on bones have given different results. It has been shown that flax seed supplementation does not affect the biomarkers of bone metabolism, while isoflavones prevent the bone loss in postmenopausal women [3]. Phytoestrogens can be effective in the reduction of other estrogen deficiency symptoms in postmenopausal women such as the hot flashes, night sweating and vaginal dryness. The preparations containing soy isoflavones have various effects on the hot flashes incidence in menopause. In breast cancer survivors, the soybean preparation did not reduce the incidence of hot flashes, while in other cases soy isoflavones exhibit a small but significant reduction of hot flashes.
The effects on the cardiovascular system

Isoflavones can exhibit their effects on the cardiovascular system in three ways:

- directly through ER-mediated effects;

- through ER-independent effects directly on cardiovascular risk factors and putative atherogenic risk factors and

- indirectly through the displacement of the animal protein intake.

Studies have shown that the consumption of soybean proteins can decrease the total and LDL cholesterol level. The effect is variable, but is generally better in patients with hypercholesterolemia than people with normal blood cholesterol concentrations. Numerous studies have shown that isoflavone supplementation has beneficial effects on serum lipids, and can lead to the reduction of the cholesterol concentration in serum. Soy isoflavones can achieve their effects by up-regulation of the LDL receptor activity [3]. Vascular endothelium is rich in ER $\beta$ and, due to high affinity to those receptors, Isoflavones have the anti-atherogenic effect [43]. It is considered that the isoflavone effect on the cardiovascular system is associated with its effect on fat metabolism. Further studies on the isoflavone effect on atherosclerosis progression are expected. It is particularly important to examine daidzein and equol effects on the cardiovascular system.<smiles>Cc1ccc(O)c(O)c1</smiles>
$\mathrm{FI}-\mathrm{OH}$<smiles>[R]C(C)C(C)C([R])C</smiles>
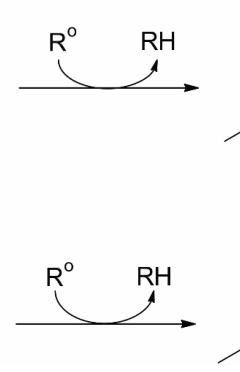

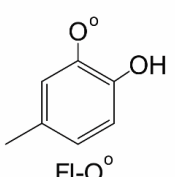

$\mathrm{FI}-\mathrm{O}^{\circ}$

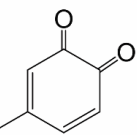

a)

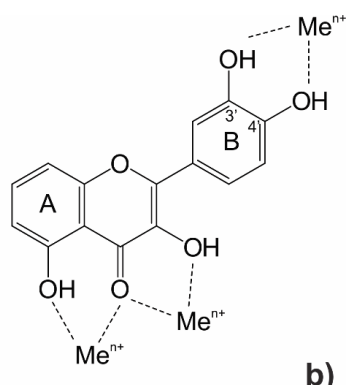

b)

Figure 12. a) Flavonoids ( $\mathrm{Fl}-\mathrm{OH})$ as scavengers of reactive oxygen compounds $\left(\mathrm{R}^{\circ}\right)$; b) binding sites for metal ions $\left(\mathrm{Me}^{n+}\right)[48]$.

\section{Cognitive effects of phytoestrogens}

A reduced estrogen amount in menopause may be associated with the increased risk for neurodegenerative diseases. The application of ERT leads to the improvement of memory in postmenopausal women. Numerous researches on the brain structure, learning, memory and anxiety in rats have shown that a high phytoestrogens intake in the relatively short period of time can significantly alter the sexually dimorphic brain regions, increased anxiety, improved learning and visual spatial memory in females, but not in males. The phytoestrogen effects on sexual dimorphism in memory are not associated with changes in the brain aromatase level. All abovementioned results are of interest in respect to the potential estrogen role in the treatment of neural disorders such as Alzheimer disease, especially in women [5].

The sleep quality is another aspect of the quality of life, especially in the period of menopause. Women in menopause have a greater number of sleep disorders and tend to feel increased fatigue. Some studies have shown that the phytoestrogen therapy can improve the quality of sleep, and have a beneficial effect on cognitive functions and insomnia [44].

\section{Antioxidant activity of phytoestrogens}

The most described and studied property of flavonoids is their ability to act as antioxidants. Antioxidants are compounds that play an important role in the organism protection against harmful effects of free radicals by neutralizing the formed free radicals or by preventing their formation. Free radicals and reactive oxygen species (ROS) are formed in human cells during normal metabolism, or under the exposure to external factors such as radiation, chemical pollution and smoke. The balance 
between oxidative stress (damage of membranes and cell surface receptors caused by oxidants) and antioxidant reparation exists in every organism [45]. The reduction of antioxidant protective effects may result in the development of many diseases, such as asthma, cancer, cardiovascular diseases, cataract, diabetes, gastrointestinal inflammatory diseases, liver diseases and others. ROS contribute to cell aging, mutagenesis, carcinogenesis and coronary heart diseases through the membrane destabilization, DNA damage and oxidation of low density lipoproteins.

As antioxidants, flavonoids protect cell membranes and organelles from the damage caused by the action of ROS. Of all flavonoids, catechins and flavones have the greatest ability to protect the organism against ROS [46]. Flavonoids can act as scavengers of free radicals and cause their inactivation. Due to the presence of highly reactive hydroxyl groups, flavonoids can react directly with free radicals to form less reactive and more stable phenolic radicals (Figure 12a) [47].

Another mechanism of the flavonoid antioxidant activity is the formation of the chelate complex with metal ions, such as copper or iron ions (Figure 12b). The presence of metal ions increases the concentration of ROS by reducing hydrogen peroxide to give highly reactive hydroxyl radicals. Flavonoids bind metal ions to form chelate complexes and inhibit the formation of hydroxyl radicals. For example, quercetin is a known flavonoid which can form chelate complexes with iron ions. It is also demonstrated that flavonoids inhibit the enzyme cyclooxygenase, lipoxygenase, microsomal monooxygenase, glutathione $\mathrm{S}$-transferase and $\mathrm{NADH}$-oxidase involved in the ROS formation. Flavonoids can interact with other physiological antioxidants such as vitamin $C$ and vitamin $\mathrm{E}$, and thus intensify their antioxidant activity [48].

\section{Conclusion}

Research in phytoestrogens has increased significantly in the past several decades. However, further investigations are still needed to evaluate the safety of phytoestrogens, beneficial and harmful doses, gender differences in response to phytoestrogens and the effects of the simultaneously phytoestrogen application with other drugs and dietary products. Phytoestrogens are represented by hundreds of various molecules classified as nonsteroidal, diphenolic compounds. Due to functional and structural differences of phytoestrogens, their biological activities are also highly variable and should be profoundly studied. It is known that phytoestrogens have beneficial effects and thus the application in different hormone-dependent cancers, cardiovascular diseases, osteoporosis, menopausal symptoms, as well as neurodegenerative diseases. However, phytoestrogens can exert several adverse effects such as infertility, the suppression of the immune system and lymphocytopenia. For these reasons, further studies should be focused on potentially adverse effects of phytoestrogen supplementation, especially when the diversity of phytoestrogens is taken into account.

\section{Acknowledgments}

This work was supported by the Ministry of Education, Science and Technological Development of the Republic of Serbia under the project TR-34012.

\section{References}

[1] A. Crozier, M. N. Clifford, H. Ashihara, Plant secondary metabolites: occurrence, structure and role in the human diet, John Wiley \& Sons, 2008.

[2] V. Tepavčević, Analiza fitoestrogena sojinog semena. Teza, Univerzitet u Novom Sadu, 2013.

[3] P. Cos, T. De Bruyne, S. Apers, D. V. Berghe, L. Pieters, A. J. Vlietinck, Phytoestrogens: Recent developments, Planta Medica, 69 (2003) 589-599.

[4] V. Gašparević-Ivanek, Fitoestrogeni, Medix, 50 (2003) 9094.

[5] R. A. Dixon, Phytoestrogens, Annual Review of Plant Biology, 55 (2004) 225-261.

[6] R. Baber, Phytoestrogens in post reproductive health, Maturitas, 66 (2010) 344-394.

[7] H. D. Nelson, Menopause, Lancet, 371 (2008) 760-770.

[8] Y. Jacquot, C. Rojas, B. Refouvelet, J. F. Robert, G. Leclercq, A. Xicluna, Recent advances in the development of phytoestrogens and derivatives: An update of the promising perspectives in the prevention of postmenopausal diseases, Mini-Review in Medicinal Chemistry, 3 (2003) 333-346.

[9] R. J. Miksicek, Estrogenic flavonoids: structural requirements for biological activity. Proceedings of the Society for Experimental Biology and Medicine, 208 (1995) 44-50.

[10] A. M. Duncan, W. R. Phipps, M. S. Kurzer, Phytooestrogens, Best practice \& research: Clinical endocrinology \& metabolism, 17(2) (2003) 253-271.

[11] J. B. Harborne, The flavonoids: advances in research since 1980, Chapman and Hall, 1988.

[12] I. M. Savić, V. D. Nikolić, I. M. Savić, Lj. B. Nikolić, M. Z. Stanković, K. Moder, Optimization of total flavonoid compound extraction from Camellia sinesis using the artificial neural network and response surface methodology, Hemijska Industrija, 67(2) (2013) 249-259.

[13] I. M. Savic, V. D. Nikolic, I. M. Savic-Gajic, Lj. B. Nikolic, K. Moder, M. Hopkins, Optimization of quercetin extraction from green tea (Camellia sinensis) using central composite design, and the pharmacological activity of the extract, Chemical and Biochemical Engineering Quarterly, 30(1) (2016) 103-115.

[14] A. Ghasemzadeh, H. Z. Jaafar, A. Rahmat, Antioxidant activities, total phenolics and flavonoids content in two varieties of Malaysia young ginger (Zingiber officinale Roscoe), Molecules, 15(6) (2010) 4324-4333.

[15] J. Tan, Dietary Isoflavones: aglycones and glycosides. PhD thesis, University of Leeds,2011.

[16] M. A. Rostagno, A. Villares, E. Guillamon, A. GarciaLafuente, J. A. Martinez, Sample preparation for the analysis of isoflavones from soybeans and soy foods, Journal of Chromatography A, 1216 (2009) 2-29. 
[17] M. Piskula, Soy isoflavone conjugation differs in fed and food deprived rats, The Journal of Nutrition, 130 (2000) 1766-1771.

[18] N. T. Pandit, V. B. Patravale, Design and optimization of a novel method for extraction of genistein, Indian Journal of Pharmaceutical Sciences, 73(2) (2011) 184-192.

[19] E. M. Bickoff, A. N. Booth, R. L. Lyman, A. L. Livingston, C. R. Thompson, F. Deeds, Coumestrol, a new estrogen isolated from forage crops, Science, 126(1957) 969-970.

[20] K. R. Price, G. R. Fenwick, Naturally occurring oestrogens in foods-a review, Food Additives \& Contaminants, 2(2) (1985) 73-106.

[21] C. H. Blomquist, P. H. Lima, J. R. Hotchkiss, Inhibition of 3a-hydroxysteroid dehydrogenase (3a-HSD) activity of human lung microsomes by genistein, daidzein, coumestrol and C 18-, C 19-and C 21-hydroxysteroids and ketosteroids, Steroids, 70(8) (2005) 507-514.

[22] A. Amin, M. Buratovich, The anti-cancer charm of flavonoids: a cup-of-tea will do!, Recent Patents on AntiCancer Drug Discovery, 2(2) (2007) 109-117.

[23] A. L. Ososki, E. J. Kennelly, Phytoestrogens: a review of the present state of research, Phytotherapy Research, 17(8) (2003) 845-869.

[24] J. Peterson, J. Dwyer, H. Adlercreutz, A. Scalbert, P. Jacques, M. L. McCullough, Dietary lignans: physiology and potential for cardiovascular disease risk reduction, Nutrition Reviews, 68(10) (2010) 571-603.

[25] H. Adlercreutz, Lignans and human health, Critical Reviews in Clinical Laboratory Sciences, 44 (2007) 483525.

[26] W. R. Phipps, M. C. Martini, J. W. Lampe, J. L. Slavin, M. S. Kurzer, Effect of flax seed ingestion on the menstrual cycle, The Journal of Clinical Endocrinology \& Metabolism, 77(5) (1993) 1215-1219.

[27] J. Higdon, Lignans, Micronutrient Information Center, Linus Pauling Institute, Oregon Stete University, 2010.

[28] I. Mattisson, E. Wirfält, U. Johansson, B. Gullberg, H. Olsson, G. Berglund, Intakes of plant foods, fibre and fat and risk of breast cancer-a prospective study in the Malmö Diet and Cancer cohort. British Journal of Cancer, 90(1) (2004) 122-127.

[29] A. Cassidy, B. Hanley, R. M. Lamuela-Raventos, Isoflavones, lignans and stilbenes-origins, metabolism and potential importance to human health, Journal of the Science of Food and Agriculture, 80(7) (2000)1044-1062.

[30] B. D. Gehm, J. M. McAndrews, P. Y. Chien, J. L. Jameson, Resveratrol, a polyphenolic compound found in grapes and wine, is an agonist for the estrogen receptor, Proceedings of the National Academy of Sciences, 94(25) (1997) 14138-14143.

[31] Ž. S. Cvetković, V. D. Nikolić, I. M. Savić, I. M. Savić-Gajić, Lj. B. Nikolić, Development and validation of an RP-HPLC method for quantification of trans-resveratrol in the plant extracts, Hemijska Industrija, 69(6) (2015) 679-687.

[32] M. Campagna, C. Rivas, Antiviral activity of resveratrol, Biochemical Society Transactions, 38 (2010) 50-53.

[33] A. A. Bertelli, L. Giovannini, D. Giannessi, M. Migliori, W. Bernini, M. Fregoni, A. Bertelli, Antiplatelet activity of synthetic and natural resveratrol in red wine, International Journal of Tissue Reactions, 17(1) (1995) 1-3.

[34] C. Giuliani, M. Iezzi, L. Ciolli, A. Hysi, I. Bucci, S. Di Santo, C. Rossi, M. Zucchelli, G. Napolitano, Resveratrol has anti-thyroid effects both in vitro and in vivo, Food and Chemical Toxicology, 107(A) (2017) 237-247.
[35] M. Jang, L. Cai, G. O. Udeani, K. V. Slowing, C. F. Thomas, C. W. W. Beecher, H. H. S. Fong, N. R. Farnsworth, A. D. Kinghorn, R. G. Mehta, R. C. Moon, J. M. Pezzuto, Cancer chemopreventive activity of resveratrol, a natural product derived from grapes, Science, 275 (5297) (1997) 218-220.

[36] T. Wallerath, G. Deckert, T. Ternes, H. Anderson, H. Li, K. Witte, U. Förstermann, Resveratrol, a polyphenolic phytoalexin present in red wine, enhances expression and activity of endothelial nitric oxide synthase, Circulation, 106(13) (2002) 1652-1658.

[37] E. K. Naderali, S. L. Smith, P. J. Doyle, G. Williams, The mechanism of resveratrol-induced vasorelaxation differs in the mesenteric resistance arteries of lean and obese rats, Clinical Science, 100(1) (2001) 55-60.

[38] A. J. Zhang, A. M. Rimando, C. S. Mizuno, S. T. Mathews, a-Glucosidase inhibitory effect of resveratrol and piceatannol, The Journal of Nutritional Biochemistry, 47 (2017) 86-93.

[39] Ž. Cvetković, V. D. Nikolić, I. M. Savić-Gajić, I. M. Savić, Lj. B.Nikolić, Ispitivanje termo i foto stabilnosti transresveratrola, Advanced Technologies, 3(2) (2014) 25-34 (in Serbian).

[40] G. Yoon, S. Park, Antioxidant action of soy isoflavones on oxidative stress and antioxidant enzyme activities in exercised rats, Nutrition Research and Practice, 8(6) (2014) 618-624.

[41] L. Bacciottini, A. Falchetti, B. Pampaloni, E. Bartolini, A. M. Carossino, M. L. Brandi, Phytoestrogens: food or drug?, Clinical cases in mineral and bone metabolism, 4(2) (2007) 123-130.

[42] S. Bedell, M. Nachtigall, F. Naftolin, The pros and cons of plant estrogens for menopause, The Journal of Steroid Biochemistry and Molecular Biology, 139 (2014) 225-236.

[43] S. Makela, H. Savolainen, E. Aavik, M. Myllarniemi, L. Strauss, E. Taskinen, P. Häyry, Differentiation between vasculoprotective and uterotrophic effects of ligands with different binding affinities to estrogen receptors $\alpha$ and $\beta$, Proceedings of the National Academy of Sciences, 96(12) (1999) 7077-7082.

[44] Y. C. Zhang, D. Albrecht, J. Bomser, S. J. Schwartz, Y. Vodovotz, Isoflavone profile and biological activity of soy bread, Journal of Agricultural and Food Chemistry, 51(26) (2003) 7611-7616.

[45] S. P. Kazazić, Antioksidacijska i antiradikalska aktivnost flavonoida, Arhiv za higijenu rada i toksikologiju, 55(4) (2004) 279-290.

[46] R. J. Nijveldt, E. L. S. Van Nood, D. E. Van Hoorn, P. G. Boelens, K. Van Norren, P. A. Van Leeuwen, Flavonoids: a review of probable mechanisms of action and potential applications, The American Journal of Clinical Nutrition, 74(4) (2001) 418-425.

[47] D. I. Hertzog, O. S. Tica, Molecular mechanism underlying the anticancerous action of flavonoids, Current Health Sciences Journal, 38(4) (2012) 145-149.

[48] S. Kumar, A. K. Pandey, Chemistry and biological activities of flavonoids: An overview, The Scientific World Journal, 2013 (2013) 1-16. 


\section{PODELA I BIOLOŠKA AKTIVNOST FITOESTROGENA: PREGLED}

Ivana Lj. Nikolić, Ivana M. Savić-Gajić, Ana D. Tačić, Ivan M. Savić

Tehnološki fakultet, Univerzitet u Nišu, Leskovac, Srbija.

Fitoestrogeni predstavljaju polifenolna i nesteroidna jedinjenja koja imaju sličnu strukturu i biološku aktivnost kao humani estrogeni. Oni su biljni sekundarni metaboliti i široko su zastupljeni u preko 300 različitih biljnih vrsta. Fitoestrogeni se dele u dve podgrupe, izoflavonoide i lignane. Izoflavonoidi se dele na izoflavone i kumestane. Izoflavoni su najzastupljeniji u soji i crvenoj detelini. Veliki broj izoflavona identifikovan je u biljkama u obliku neaktivnih glikozida (daidzein i genistein) i 4'-metilovanih derivata (formononetin i biohanin A). Kumestani se takođe mogu naći u crvenoj detelini i mahunarkama, dok su lignani najzastupljeniji u semenu lana. Kumestani imaju najizraženiji estrogeni efekat od svih fitoestrogena. Najpoznatiji predstavnik iz ove podgrupe jedinjenja je kumestrol. U lignane spadaju matairezinol, sekoizolaricirezinol, laricirezinol, pinorezinol i njihovi metaboliti, enterodiol, enterolakton i ekvol. Brojne studije na životinjama i ljudima su pokazale da fitoestrogeni mogu da imaju zaštitne efekate na estrogen-zavisna stanja i estrogen-zavisne bolesti. Takođe je poznato da upotreba fitoestrogena može da ima pozitivan efekat na nesanicu i kognitivne funkcije, odnosno nervne poremećaje kao što je Alchajmerova bolest. Oni ispoljavaju antioksidativnu aktivnost na dva načina, kao hvatači slobodnih radikala ili formiranjem helatnih kompleksa sa jonima Fe i Cu. Slobodni joni metala povećavaju količinu reaktivnih vrsta kiseonika redukcijom vodonik-peroksida, stvarajući veoma reaktivne hidroksi radikale.
(PREGLEDNI RAD)

UDK 577.175.6:615.322.07 farmakološka aktivnost. 